\title{
School Culture and Spirituality in Workplace
}

\author{
Abdul Ghani Kanesan Abdullah \\ School of Educational Studies, Universiti Sains Malaysia, Penang, Malaysia \\ Ying-Leh Ling \\ Politeknik Kuching Sarawak, Sarawak, Malaysia \\ Azians Binti Abu Hassan \\ School of Educational Studies, Universiti Sains Malaysia, Penang, Malaysia
}

\begin{abstract}
This quantitative descriptive study aimed to identify the influence of school culture on spirituality in workplace. A total of 540 randomly selected teachers were selected from 36 secondary schools in Penang as respondent in the study. Data for this survey were collected through a questionnaire which was adapted from literature review (AlAmin, 2012; Maslowski, 2001; Milliman et al., 2002; Yaakob, 2007). The results of multiple regression analysis showed that school culture had positive and significant influence on spiritual at workplace. In term of the implications, this study showed that the leaders need to inculcate spirituality at work by creating a positive culture.

Keywords: School culture; Workplace spiritual.
\end{abstract}

\section{Introduction}

The concept of spirituality, which includes pitch, cooperation, excellence, manners and trust is increasingly popular and has gained a place in the Malaysian education system (Ibrahim, 1995). Nasina and Koh (2011) argue that spirituality in the workplace can solve human capital problems because of its special role in the organization. This integration is not merely for financial benefit but includes the integration of vision and goals. We need to be aware of the existence of a positive school culture that brings power that can bring together goals, motivation, commitment, and loyalty to all schoolchildren. This means that positive workplace culture can develop and increase the motivation and commitment of members in the organization in order to achieve the vision and mission set. According to Smith (1984), positive organizational climate has characteristics such as positive working environment and good social relationships between individuals. Thus, leaders need to have an efficient humanitarian skill in carrying out their duties as they deal with humans.

Work culture is often associated with a conducive environment and it can help improve organizational performance. Empirical findings have also proven work culture as a determining factor in the effectiveness of the task entrusted and organizational excellence (Jaafar, 2004). School culture is the dominant values that are supported by all the school makers who demand the wisdom of school attendees to integrate the elements and components of the school together with the value of individual work within the organization. In the context of school culture, it contains patterns, ideas, norms, thoughts and values that contribute to the formation of individual behaviour. The creation of a school culture requires the commitment of all its citizens to mobilize to mobilize the machinery of the organization towards mutual goals and goals. This is confirmed by the findings of Lee (1991) showing the dimensions of organizational culture being examined have significant and positive relationships with work performance.

Undeniable spirituality in the workplace has its significance. Jaafar (2004) emphasizes the integration of spirituality in the workplace, work value, and school culture are expected to improve school performance. This is because spirituality not only enhances values and ethics but also improves self-esteem, satisfaction and sense of belonging. That sequence, it will increase the performance of the work and then will be able to achieve the mission and vision of the organization. According to Fry (2003) the visible change seen in today's professional world is an effort to integrate the world's spirituality with organizational management. This integration is not solely for financial benefit but also includes the consolidation and coordination of organizational vision and goals. This integration can indeed facilitated by the creative leader.

Herman and Gioio (1998) have explained the spirituality in the workplace is the essence of an organization that connects individuals with other individuals who can turn the atmosphere of working as a happy family. Leaders who can revitalize spirituality in the workplace will transform the organization from activities that focus on achieving the goal of a place to promote integration among workers (Nada et al., 2002), without pressure. This will lead to 


\section{Sumerianz Journal of Education, Linguistics and Literature}

increased productivity and work performance. It should be noted that spirituality at work or at school is important because individuals spend most of their day at work (Neck and Milliman, 1994). Therefore, the comfort and excitement of work must be in an organization or school because of its impact on motivation, commitment (Delbecq, 1999) and employee emotions (Al-Amin, 2012); (Tischler et al., 2002). The spirituality produced in a school not only gives meaning to teachers but also impacts on human capital that will ultimately impact the development of society and the nation. Hence, researchers see that there is a need to study the culture of school and spirituality in the workplace which is the cornerstone of increased productivity. In particular, this study examines the extent to which school culture influences the impact of spirituality in the workplace.

\section{Literature Review}

\subsection{School Culture}

School culture is defined as the personality and personality of the school that affects the way it works. Deal and Peterson (1994) also see school culture as a set of norms and values, rituals and traditions, and long-established stories that enable them to work and learn together. In that regard, Yaakob (2007) has referred to the concept of school culture as a way of life that embraces school practice both outside and in the classroom that reflects the values, beliefs, and norms shared by its citizens. In this regard, school culture affects every component in a school (Ruhani, 2009) and will help and support the effectiveness of teacher teaching (Alimuddin, 2009).

Quinn and Rohrbaugh (1983) have outlined four elements in the school culture that include humanitarian relations, internal processes, rational goals, and open system orientations to determine patterns or groups in identifying the key to organizational effectiveness. The dimension of humanitarian relations based on the fundamental ideas formulated by the movement of humanitarian relations in organizational theory. The movement of humanity in administration and believes the fundamental challenge in all organizations is to develop and maintain a dynamic and harmonious relationship. In this dimension, important values are organizations that have high-spirited members, respecting others, and high commitment to organizations in an open environment to ensure that there is a discussion in decision-making. This dimension emphasizes interpersonal relationships and flexible operations, where the organization considers the agreement and spirit that ultimately develops human resources. This dimension provides space for individual development and good interpersonal relationships where leaders play the role of mentors and facilitators. As a facilitator, leaders need to inject the spirit of cooperation, unity and teamwork and take care of interpersonal conflicts. Leaders need to understand their main task instead of building a team of work and mentoring, but they play a role in developing individual potential in a way that is pleasing.

The dimensions of this open system have relationships with values related to the change of state and organizational environment. In this case, the organization relies on its environment to obtain inputs and can only operate in the same behaviour and be adopted as legitimate in the group. This shows that the organization needs to adapt to their environment either proactively or reactively. The key value in this dimension is the value required to obtain resources for organizational maintenance and expansion, as well as for the outside support of customers, owners or shareholders in the environment. This dimension emphasizes the flexibility and willingness to act in order to achieve goals, resources, outside support and expansion. Members in the organization are free to work, dare to take risks and responsibilities. Under this dimension, the leader acts as an innovator and broker in his workplace. The innovator leader needs to provide space for adaptation and change, while as a broker, leaders need to ensure external acceptance of the organization.

Dimension of rational goal was depicted through a pragmatic approach to the organization as an entity that has a roadmap to achieve the goal. In some cases, this dimension exists in parallel with the dimension of the internal process that attempts to control the organization in a rational way to achieve the desired goal (Maslowski, 2001). The main value of this dimension is productivity and effectiveness. To achieve organizational goals, goals should be clear, feedback and rational goals are essential. This dimension leads to high productivity and economic operations through planning and setting targets as tools. In this case, individual goals are determined by the organization's goals. High achievement is needed and assessments are performed by the leader. Leaders will act as directors and producers. As a director, leaders explain the expectations of the organization through planning and setting goals, and as producers, leaders lead to work orientation and focus on work.

Internal process dimensions explain that organizations can operate effectively when an action is clearly identified and coordinated in an efficient manner. This dimension contains an organizational management perspective based on the work of Weber, the bureaucracy and the early work of the scientific management movement. The values emphasized in this dimension are stability, reliability and efficiency. Organizational goals or goals can be achieved by means of operations and clear communication systems, management information and documentation are believed to be the most important means of achieving organizational goals. 


\section{Sumerianz Journal of Education, Linguistics and Literature}

Emphasis is also given to stability and oversight through effective information and communication systems. This dimension provides clear working goals, strict rules and at the same time emphasizing employee safety. The leader serves as a supervisor and coordinator. During supervision, leaders need to know what is happening in the unit, ensuring staff follow the rules and meet the goals set. As coordinator, the leader retains the structure and flow of the system (Quinn and Rohrbaugh, 1983).

\subsection{Workplace Spirituality}

Spirituality is a backbone and joyful relationship as well as enhances the motivation of workers in carrying out their duties. Bowman (2004) emphasizes the spirituality in the workplace in relation to the desire, intimacy, tolerance, and intuition to carry out the responsibilities that have been given. The pioneers of the concept of spirituality at workplace namely Ashmos D. P. and Duncon (2000) have identified seven dimensions. Milliman et al. (2002) used three dimensions from the study of Ashmos D. P. and Duncon (2000), meaningful dimensions of work (individual level), dimensions of community feeling (group stage), and dimensions along with organizational value (organizational level) because it includes the context of individuals, groups, and organizations.

A meaningful work is a dimension that describes the individual stage of performing meaningful work. This dimension is the most important dimension in every organization because it is the dimension that will move the organization into the lower level of work. In this dimension, each individual is assumed to have self-motivation and trust and desire for meaningful activities in the individual's life and others (Ashmos D. P. and Duncon, 2000; Milliman et al., 2002). According to Milliman et al. (2002), this dimension shows how workers themselves interact in their daily work. The reduction of spirituality in the workplace involves the careers and unions to find the purpose and identity of the workplace (Milliman et al., 2002), by finding the true meaning of working and how one individual can contribute to others (Ashmos D. et al., 1999).

Furthermore, the second dimension in this model is the dimension of community feeling explaining the feelings of the community that belong to the group stage category and this dimension is said to be the most critical dimension as it involves relationships with others that will promote the feeling of community (Ashmos D. P. and Duncon, 2000; Milliman et al., 2002). The community in question is an organization environment that involves interaction between individuals with colleagues and management. This is also explained by Kamran (2011) that are the relationship that exists in relation to the relationship between the individual and the individual and the relationship between the individual and the other.

The relationship between individuals and other individuals is based on trust. Neal and Banner (1991) used the word "spirit de corps" in this dimension to illustrate the relationships between workers involving mental, emotional, and spiritual elements. Milliman et al. (2002) also explains this dimension involves the feeling of connecting with others, feelings of support, freedom of expression and natural feelings. After all, there will be a new work culture that will help the organization succeed if this dimension can be implemented within an organization.

The last dimension at the organizational level is the dimension along with the value of the organization. This dimension explains the relationship between employee interaction with the organization's major goals (Kamran, 2011), where the goals of employees and organizations should be aligned to contribute to society. In this case, the value of work owned by an individual needs to be in line with the goals of the organization. This dimension will only apply if the individual working value can be attributed to the mission and vision of the organization. This dimension encourages employees to work better and have a positive working value in order to contribute to organizational excellence. Certainly, the organization expects high integrity value of employees because employees are not just contributing to the organization and the community but the contributions they give must be extraordinary (Milliman et al., 2002) and more meaningful. Not only that, employees are also expected to have a high commitment in achieving organizational vision. That sequence, the successful workers and organizations building together, will be able to make a meaningful contribution to society.

\section{Research Methodology}

\subsection{Research Design}

This study uses a quantitative approach in the form of a cross-sectional study. This is because the survey method is found to be suitable for the purpose of this study, which is to collect information from many respondents. The quantitative approach used to illustrate, examine relationships, and identifying cause and effect. This coincides with the opinions of Gay et al. (2012) where the design of this study is most appropriate for large populations because the uniformity of facts and information can be interpreted from the respondents systematically. 


\subsection{Population and Sampling}

The population of this study consists of national secondary schools in Penang. A total of 89 schools participated in this study. The following table shows the study population representing the district in Penang with a teacher population of 6026 people.

\begin{tabular}{l|l|l}
\multicolumn{3}{|l|}{ Table-1.The population of national secondary schools and the number of teachers in Penang state } \\
\hline District & Total schools & Total teachers \\
\hline North East & 24 & 1550 \\
\hline Southwest & 10 & 691 \\
\hline Seberang Perai Utara & 23 & 1724 \\
\hline Seberang Perai Tengah & 21 & 1467 \\
\hline Seberang Perai Selatan & 11 & 594 \\
\hline Jumlah & 89 & 6026 \\
\hline Source: Penang State Education Department (2014)
\end{tabular}

Simple random sampling was used in this study. Of the 89 regular secondary schools in Penang, only 39 regular daily high schools were selected as samples of this study. Subsequently, to determine the number of schools from the regular daily school list, systematic sampling has been used. Accordingly, 540 teachers were randomly selected based on the calculations of Krejcie and Morgan (1970). The selected sample must be trained teachers and have been in school for not less than a year. This is to ensure that selected teachers have the experience and understand the current school work situation.

\subsection{Research Instrument}

In this study, the instrument used consists of a set of questionnaires containing three parts. Part A consists of teacher demographic information. Next, Section B covers 42 items used to identify dimensions of work culture that emphasize organizational effectiveness. In this study, school culture is divided into four dimensions: humanitarian relations (11 items), open system dimensions (10 items), rational goal dimensions (10 items), and internal process dimensions (11 items). This questionnaire is adapted from Maslowski (2001) and it was used by Yaakob (2007). While Section C contains items related to the spirituality variables in the workplace. A total of 20 items are contained in this section based on three dimensions of spirituality in the workplace. This section is adapted from Milliman et al. (2002) and has been translated by Al-Amin (2012). In this study, three dimensions of spirituality at work include meaningful work dimensions (6 items), dimensions of community feeling (6 items), and dimensions along with organizational value ( 8 items). Respondents are required to answer questionnaires based on Likert scale

\subsection{Pillot Tests}

Pilot research is a study conducted before the actual study is conducted. Chua (2006) sees a pilot study as a feasible study feasible in the real situation of selected respondents. A total of 110 teachers participated in the pilot study of two regular secondary schools in Seberang Perai Utara, Penang. In this study, the Alpha Cronbach coefficients are used to test the reliability of the instrument for actual study. Alpha Cronbach's analysis of school culture instruments was as high as .95 and every school cultural dimension was at 82 to .95 . In this regard, the reliability value of the spirituality items at the workplace is .93 where the reliability value of each dimension is between .83 to .93 . The following table shows the reliability value for each dimension.

Table-2. Cronbach Alpha value for items in school cultural dimensions and spirituality at work

\begin{tabular}{l|l|l}
\hline Variable & Dimension & Cronbach Alpha Value \\
\hline School culture & & .92 \\
\hline & Humanitarian relationship & .89 \\
\hline & Open system & .90 \\
\hline & Rational goal & .88 \\
\hline Spirituality in school & Internal process & .82 \\
\hline & & .93 \\
\hline & Meaningful work & .83 \\
\hline & Community feeling & .84 \\
\hline & Along with the value of the organization & .93 \\
\hline
\end{tabular}




\subsection{Data Collection Procedure}

The collection of data for the actual study was started after obtaining the approval from the panel of research proposals of the Center for Educational Studies, Universiti Sains Malaysia. Before the study was conducted in schools, researchers first applied for permission from Research Planning and Research Policy Division, Ministry of Education, Malaysia. Subsequently the application for permission was submitted to the Penang State Education Department to conduct actual studies at selected schools in Penang. Data collection has been conducted throughout January to April 2015.

\section{Research Findings and Discussion}

Separate multiple regression analysis has been done on testing the influence of school culture on the three dimensions of spirituality in the workplace including meaningful work, community feeling, and in line with organizational value. Four dimensions in school culture comprise humanitarian relations, open systems, rational goals, and internal processes. The findings of the study were presented in the following table.

Table-3. The value of the $\beta$ coefficient value $\mathrm{F}$ or the influence of school culture on the spirituality of the workplace

\begin{tabular}{l|l|l|l}
\hline Independent variable: & \multicolumn{3}{|l}{ Dependent variable: Spirituality in workplace } \\
\cline { 2 - 4 } & $\begin{array}{l}\text { Meaning work } \\
(\boldsymbol{\beta})\end{array}$ & Community feeling $(\boldsymbol{\beta})$ & $\begin{array}{l}\text { Along with the value } \\
\text { of the organization } \\
(\boldsymbol{\beta})\end{array}$ \\
\hline Humanitarian relationship & $.168^{*}$ & .054 & $.342^{*}$ \\
\hline Open system & $.178^{*}$ & $.228^{*}$ & -.069 \\
\hline Rational goal & -.012 & .049 & $.170^{*}$ \\
\hline Internal process & $.234^{*}$ & $.229^{*}$ & $.260^{*}$ \\
\hline $\mathrm{R}$ & .498 & .506 & .627 \\
\hline $\mathrm{R}^{2}$ & .248 & .256 & .393 \\
\hline Adjusted $\mathrm{R}^{2}$ & .241 & .249 & .388 \\
\hline F value & 36.3 & 37.9 & 71.5 \\
\hline Durbin Watson & 1.95 & 1.94 & 1.83 \\
\hline * Significant at $p<.05$ level & \multicolumn{2}{l}{} \\
\hline
\end{tabular}

The results of multiple regression analysis showed that all the dimensions of school culture contributed 24.8 percent change in workplace spirituality variance for meaningful dimensions of work. The findings of multiple regression analyses also show dimensions of humanitarian relations $(\beta=.168, p<.05)$, open system dimensions $(\beta=$ $.178, p<.05)$, and internal process dimensions $(\beta=.234, p<.05)$ have a significant influence on workplace spirituality for meaningful dimensions of work. This indicates that school culture has a significant influence on meaningful work. In other words, when school culture is strengthened apart from the dimensions of rational goals, it improves spirituality in the workplace for dimension of meaningful in work.

In addition, the findings from multiple regression analyses also show that all dimensions for school culture variables contribute about 25.6 percent change in the spirituality variance in the workplace in dimensions of community feeling. The findings of multiple regression analysis show the open system dimensions $(\beta=.228, p<.05)$ and the internal process dimensions $(\beta=.229, p<.05)$ have a significant effect on the feeling of community. This means that school culture is strengthened apart from dimensions of humanitarian relations and rational goals, it also improves spirituality in the workplace for dimension of sense of belonging.

In this regard, the findings show that all dimensions of school culture have contributed as much as 39.3 per cent of variance in spirituality in the workplace under dimensions in line with organizational value. The findings of the multiple regression analysis show the dimensions of humanitarian relations $(\beta=.342, p<.05)$, rational goal dimensions $(\beta=170, p<.05)$, and internal processes $(\beta=.260, p<.05)$ have a significant effect on the dimensions along with organizational value. This finding suggests that if school culture is enhanced beyond the open system dimension, it will increase the dimension along with organizational value in the workplace.

The overall findings have shown that school culture variables have significant relationships with workplace spirituality. School culture, especially for the dimensions of the internal processes, affects the three dimensions of spirituality in the workplace, which is meaningful work, community feeling and in line with organizational value. This is because the process that takes place in the school will move teachers and school staff towards achieving the goals of the school that will make the activities of teachers more meaningful, the existence of community feelings and teachers will work to achieve the goals that have been planned.

This internal process dimension guides the organization in achieving the desired goal as in the finding of Ajala and Mojoyinola (2013) which is the factor of forming a quality work culture comprising focus on customer, staff involvement, leadership commitment, organizational quality planning and the existence of reward system and quality 


\section{Sumerianz Journal of Education, Linguistics and Literature}

sharing. According to Ajala and Mojoyinola (2013), the practice and appreciation of positive values in the organization will enable the employee to carry out his duties with full commitment and collective, and ensure the smooth running of the organization.

The dimension of humanitarian relations affects two of the three dimensions of spirituality at work which is meaningful job and in line with the value of the organization. The positive interactions that exist among the school staff will make teachers feel the work they do more meaningfully. These interactions will also affect the goals that teachers will achieve. As a teacher, the goal is to achieve the goal of the school. This collaborative culture will enhance teachers' motivation (Abdul and Tang, 2006).

Likewise with an open system that affects a significant dimension of work and a sense of community. Whereas, the dimensions of the rational goal affect the dimensions along with the value of the organization. This explains that school culture affects spirituality in the workplace and is able to enhance the effectiveness of the organization. The findings are consistent with the opinions expressed by Milliman et al. (2002) that the union or community should involve mental, emotional, and spiritual elements to connect between workers.

The relationships that exist in the school will not only elevate spirituality but also provide strength and endurance to teachers in the face of any obstacles to achieving school goals. The strength within one's includes physical, emotional and intellectual strength and one's living culture.

\section{Conclusion}

The education world is witnessing the rapid development of science to cause the orthodox education system to be replaced with a new millennium education system that is more concerned with the latest empirical findings to meet the demands of science treasures. The results of the study will provide guidance to educator groups as effective generation leaders and managers in order to create a more positive school climate.

Based on the results of the research, leaders need to inculcate spirituality at work by creating a positive culture. Among positive cultural features are community feelings, intimate relationships among organizational citizens, teamwork, and rejoicing while working. Thus, it is believed that organizations with a positive culture can be seen through the cheerfulness shown by the organization's employees while working and when undertaking various activities or programs designed by the organization.

\section{References}

Abdul, G., K. A. and Tang, K. N. (2006). Motivasi guru dan pengurusan budaya kolaboratif pengurus pendidikan wanita. Jurnal Pendidikan, 31: 97-105.

Ajala, E. M. and Mojoyinola, J. K. (2013). Spirituality in health care and industrial welfare: needs for its integration in social work education. A paper presented at the 8th North American Spirituality and Social work Conference at University of Puerto Rico, Rio Piedras Campus. Puerto Rico: USA.

Al-Amin, M. (2012). Pengaruh peranan transformasi pengetua terhadap hubungan antara spiritualiti dengan komitmen guru. Tesis Doktor Falsafah yang tidak diterbitkan. Universiti Sains Malaysia: Pulau Pinang.

Alimuddin, M. D. (2009). Budaya sekolah pengaruhi keberkesanan pengajaran. Pendidik. http://pendidik.com.my

Ashmos, D., Duchon, D. and Laine, K. (1999). Spirituality at work: A conceptualization and measure. Southwest Academy of Management Proceedings: Houston, Texas.

Ashmos, D. P. and Duncon, D. (2000). Spirituality at work: A conceptualization and measure. Journal of Management Inquiry, 9(2): 134-45.

Bowman, T. J. (2004). Spirituality at work: An exploratory sociological investigation of The Ford Motor Company. Unpublished dissertation for Doctor of Philosophy $(\mathrm{PhD})$ in Political Science.

Chua, Y. P. (2006). Kaedah penyelidikan. McGraw Hill Sdn Bhd: Malaysia.

Deal, T. E. and Peterson, K. D. (1994). The leadership paradox: Balancing logic and artistry in schools. Josey Bass Publisher. Inc: San Francisco, CA.

Delbecq, L. A. (1999). Christian spirituality and contemporary business leadership. Journal of Organizational Change Management, 12(4): 345-59.

Fry, L. W. (2003). Toward a theory of spiritual leadership. The Leadership Quarterly, 14: 693-757.

Gay, L. R., Mills, G. E. and Airasian, P. W. (2012). Educational research: Competencies for analysis and application. 10th edn: Pearson: Boston.

Herman, R. E. and Gioio, J. L. (1998). Making work meaningful: Secrets of the future-focused corporation. The Futurist, 33(9): 24-38.

Ibrahim, A. B. (1995). Peningkatan pelbagai jenis literasi khususnya literasi saintifik dan teknikal: Ke arah pemantapan martabat kepimpinan yang unggul. Jurnal Pengurusan Pendidikan, 4(2): 1-19.

Jaafar, M. (2004). Kelakuan organisasi (Ed. ke-3). Leeds Publications: Kuala Lumpur.

Kamran, E. A. (2011).'Spirituality in workplace and its impacts on the efficiency of management. 2nd International Conference on Business and Economic Research (2nd ICBER 2011) Proceeding'. Conference Location.

Krejcie, R. V. and Morgan, D. W. (1970). Determining sample size for research activities. Educational and Psychological Measurement, 30(3): 607-10. 
Lee, M. (1991). Spirituality in organizations: Empowerment and purpose. Management Education and Development, 22(3): 221-26.

Maslowski, R. (2001). School culture and school performance. Unpublished Doctoral thesis. University of Twente.

Milliman, J., Czaplewski, A. J. and Ferguson, J. (2002). Workplace spirituality and employee work attitudes: An exploratory empirical assessment. Journal of Organisational Change Management, 16(4): 426-27.

Nada, K. K., Kouzmin, A. and Kakabadse, A. (2002). Spirituality and leadership praxis. Journal of Managerial Psychology, 17(3): 165-82.

Nasina, M. D. and Koh, P. P. (2011). The workplace spirituality and affective commitment among auditors in big four public accounting firms: Does matter? Journal of Global Management, 2(1): 216-26.

Neal, J. A. and Banner, D. (1991). Spirituality perspectives on individual, organizational and societal transformation. Journal of Organizational Change Management, 12(3): 24-36.

Neck, C. P. and Milliman, J. F. (1994). Thought Self-leadership, finding spiritual fulfilment in organizational life. Journal of Managerial Psychology, 9(6): 9-16.

Quinn, R. E. and Rohrbaugh, J. (1983). A spatial model of effectiveness criteria: Towards a competing values approach to organizational analysis. Management Science, 29: 363-77.

Ruhani, M. M. (2009). Budaya sekolah: Implikasi terhadap proses pembelajaran secara mengalami. Jurnal Kemanusiaan, 13: 63-78.

Smith, P. B. (1984). The effective of Japanese style of management: A review and critique. Journal of Occupational Psychology, 57(2): 121-36.

Tischler, L., Biberman, J. and McKeage, R. (2002). Linking emotional intelligence, spirituality and workplace performance: Definitions, models and ideas for research. Journal of Managerial Psychology, 17(3): 203-18.

Yaakob, D. (2007). Budaya sekolah rendah: Hubungannya dengan kepemimpinan komitmen organisasi dan pencapaian akademik murid. Tesis Doktor Falsafah yang tidak diterbitkan. Universiti Sains Malaysia: Pulau Pinang. 